\title{
The characteristics and development of the Swiss franc repurchase agreement market
}

\author{
Sébastien Kraenzlin
}

Published online: 2 March 2007

(C) Swiss Society for Financial Market Research 2007

\begin{abstract}
With the reinterpretation of repurchase agreements (repos) by the tax authority and the revision of the national bank law in 1997, allowing the Swiss national bank (SNB) to use repos as monetary policy instrument, the prerequisites for the development of a Swiss franc repo market were given. The development of the repo market in Switzerland only came up in 1999 with the provision of an integrated trading and settlement system provided by SegaInterSettle AG (SIS), Eurex and Swiss Interbank Clearing (SIC) in collaboration with the SNB. The following paper provides an overview of the basic characteristics and structure of the Swiss franc repo market as well as of the development it has undergone since 1999. It also discusses what motives and reasons the banks possess to actively participate in the Swiss franc repo market.
\end{abstract}

Keywords Repurchase agreement $\cdot$ Monetary policy $\cdot$ Switzerland $\cdot$ Interbank market

JEL Classification $\quad \mathrm{E} 40 \cdot \mathrm{E} 52 \cdot \mathrm{E} 58$

The content of the publication is the sole responsibility of the author and does not necessarily reflect the views of Credit Suisse.

S. Kraenzlin $(\varangle)$

Department of Economics (WWZ), University of Basel, Feierabendstrasse 12,

4051 Basel, Switzerland

e-mail: Sebastien.Kraenzlin@unibas.ch

S. Kraenzlin

Economic Research Department, Credit Suisse, Zurich, Switzerland 


\section{Introduction}

Until the end of 1996, a stamp tax, in the form of a turnover tax, was levied on securities sales (including repurchase agreements (repos)) in Switzerland, which made it unattractive for commercial banks to use repurchase agreements and prevented the development of a domestic repo market. From the beginning of 1997, tax authorities in Switzerland reinterpreted repos as a refinancing transaction, omitting the tax levied. In addition to the reinterpretation, the national bank law was revised in November 1997 allowing the Swiss National Bank (SNB) to use repos as an operational instrument for monetary policy purposes. While the Swiss franc repo market was finally launched in April 1998, the development and attractiveness of this market only came up with the provision of an integrated trading, clearing and settlement system provided by SegaInterSettle AG (SIS), Eurex and Swiss Interbank Clearing (SIC) in collaboration with the SNB. Since then the market has substantially increased reaching outstanding volumes of up to CHF 70 billion until June 2005. A division of the Swiss franc repo market into two parts, namely in a so-called interbank and a SNB market, reveals that in contrast to the interbank market, the latter one-which the SNB uses for monetary purposes - attained high outstanding volumes from the beginning. The immediate upsurge of the outstanding volume in the SNB market can be ascribed to the fact that the SNB has almost exclusively used repos to implement its monetary policy since 1999. Additionally, the adoption of the new monetary policy framework in 2000 has further increased the importance of repos and supported the development. ${ }^{1}$ Only from April 2004 onwards did the outstanding interbank volume surpass the one of the SNB market and remain higher for most of the time.

Of the few publications on the Swiss franc repo market, the paper by Jordan and Kugler (2004) stands out. With data from January 2000 to September 2003 they show that the SNB has had a statistically significant influence on the $3 \mathrm{M}$-Libor volatility. By fully meeting the banks liquidity needs, the SNB was able to minimize interest rate volatility. In addition they found out that there exists a volatility trade-off with respect to the maturity structure of repo transactions used for monetary policy. Relying more on repos with a 1-day maturity decreased (increased) the volatility of the $1 \mathrm{~W}$-Libor (1M- and 3M-Libor), while using week maturities increased (decreased) the volatility of the $1 \mathrm{~W}$-Libor (1M- and 3M-Libor). A calculation of the variance of the 3M-Libor, defined as the average of squared deviations from the target rate, ${ }^{2}$ reveals that the SNB has managed to reduce the volatility from up to 23 basis points (bp) in 2002 to $1 \mathrm{bp}$ in 2005. Considering that in 2004 and 2005 the SNB has mainly used 1 week repos-and much less overnight repos than in 2002-to implement its

\footnotetext{
1 For more information on the new monetary policy framework and the steering of the 3M-Libor, see Veyrassat (2001).

2 The definition by the SNB where the 3M-Libor should be, was taken as the target rate. Where no statement was made by the SNB, the middle of the target range was taken. Additionally the level of the interest rate was taken into account.
} 
monetary policy, the decrease in the volatility supports the finding of Jordan and Kugler (2004). Overall it can be concluded that the new monetary policy framework as well as the use of repos as monetary policy instrument has led to a successful implementation of Swiss monetary policy and to a rather precise steering of the 3M-Libor. ${ }^{3}$

The aim of the following paper is to provide the reader with an overview of the basic characteristics and structure of the Swiss franc repo market as well as of the development it has undergone since 1999. The first part of the paper is divided into four sections. The first two sections provide the reader with a definition of a repurchase agreement and a brief overview of the characteristics of the Swiss franc repo market. The range of eligible collateral as well as the trading, clearing and settlement in Switzerland also known as Swiss Value Chain, and the implied risks will be described and discussed in the last two sections.

The second part of the paper provides a more detailed overview of the development of the interbank and SNB market. As will be seen in the following, the Swiss franc repo market is dominated by three bank groups among which also the group 'banks from abroad' figures. Hence the question on the motive of the domestic as well as of foreign banks arose. The second part of the paper will deal with this question and provide possible explanations. Finally the implementation of the SNB's monetary policy via repurchase agreements, especially the almost daily liquidity provision through fixed rate tenders, and the standing facilities are presented and illustrated.

\section{The characteristics of the Swiss franc repo market}

\subsection{A definition of repurchase agreements}

A repurchase agreement is a financial transaction in which a so-called cash taker sells securities (as collateral) to obtain money from a cash provider. ${ }^{4}$ At the same time the two parties agree to reverse the transaction at a pre-specified date. At this date the cash taker will buy back the securities and repay the loan plus the accrued repo rate, which normally depends on the maturity of the transaction and the securities provided. As the cash taker will repurchase the securities delivered, he virtually remains exposed to the market risk, which is why he remains the beneficial owner of these securities. ${ }^{5}$ In case the cash taker should default during the term, the cash provider is empowered to sell the securities. On the other hand, should the cash provider default, the cash taker can use the cash amount to replace the securities he provided as collateral.

\footnotetext{
3 A discussion and empirical analysis on the predictability and transparency of central banksamong others the SNB - can be found in Hock and Zimmermann (2005) and Wilhelmsen and Zaghini (2005).

${ }^{4}$ From the cash provider point of view the transaction is called reverse repurchase agreement.

5 This thus implies that the cash taker retains the right of dividend and/or interest distribution for example.
} 
A repurchase agreement can thus be regarded as a secured loan, nearly eliminating total counterparty risk.

Apart from the 'traditional' repurchase agreement, which is also known as general collateral (GC) repo, participants can also conduct special collateral repos. Again one party delivers cash while the other party provides the collateral. But in contrast to GC repos, where the main purpose is the borrowing of short-term liquidity funds, special repos serve for financing long securities positions and covering short securities positions. ${ }^{6}$ Hence the securities delivered are of primary importance and not the cash. Just like in the GC repo, the cash provider will receive the accrued repo rate at the repurchase date. However, as the main purpose of the transaction is the borrowing of the securities, the cash provider will have to pay a so-called fee, which depends on the 'specialness' of the security. Generally the fee is less than the repo rate, which is why the cash provider will still receive a positive accrued interest rate. From early August to mid-November of 2003, however, special circumstances led market participants in the U.S. to lend money at negative interest rates to borrow a particular Treasury note. ${ }^{7}$ This was mainly due to the increasing ancillary costs of failing on an obligation to deliver Treasury securities as well as the rather low level of interest rates. Until June 2005 this has never happened for special repos conducted via the Swiss repo system.

\subsection{The Swiss franc repo market}

Since the omission of the stamp tax on repos and the provision of an integrated trading and settlement system provided by SegaInterSettle AG (SIS), Eurex and Swiss Interbank Clearing (SIC) ${ }^{8}$ in collaboration with the SNB, the Swiss franc repo market has substantially developed. The Swiss franc repo market can notionally be split into two parts, namely into a so-called interbank market and a SNB market. All repo transactions that are concluded between banks belong to the interbank market, while repos involving the SNB are assigned to the SNB market. As can be seen in Fig. 1, the outstanding volume on the interbank market developed slowly, surpassing the outstanding volume in the SNB market only in April 2004. The immediate upsurge in the outstanding volume of the SNB market can be explained by the fact that the SNB started using repos to implement its monetary policy, which almost exclusively replaced currency swaps as main policy instrument by the year $2000 .^{9}$

The SNB and interbank market also differ with respect to the maturities traded. On the SNB market all transactions, with the exception of the year 1999, during which two and three month repos were traded, had maturities up to one month. On the interbank market, in contrast, $50 \%$ of the outstanding

\footnotetext{
6 Veyrassat (2004), p. 46.

7 See Fleming and Garbade (2004) for a further discussion.

8 For a detailed description of the SIC System see Heller et al. (2000).

9 See Jordan and Kugler (2004).
} 


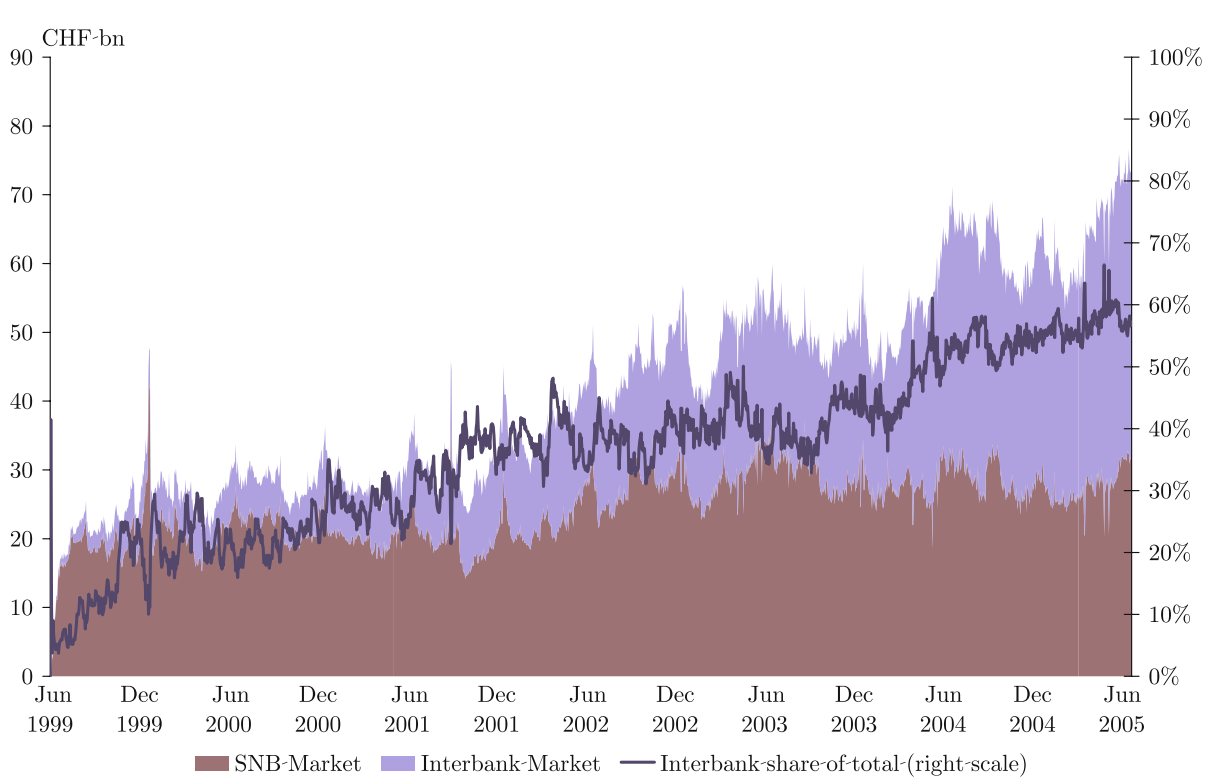

Fig. 1 Outstanding SNB and Interbank Market Volume ( ${ }^{a}$ Including intradey transactions). Source: Eurex

volume was due to repos with a term of 2 months and above. This finding can be ascribed to the fact that the SNB prefers shorter-term repo transactions as these mature more frequently and thus allow more flexibility on the implementation of monetary policy. The flexibility is insofar given as the SNB can adjust its liquidity supply by conducting new repo transactions or not, more often than with longer-term repos. In addition, less short-term repo transactions were conducted on the interbank market, as a great extent of the short-term liquidity needs had already been satisfied by the SNB. On average the SNB market accounted for $78 \%$ of the outstanding volume of short-term maturities (from Overnight to 1 month, excluding intraday) from June 1999 to June 2005.

Compared to the number of trades and outstanding volume of GC transactions in the interbank market, special repos have developed poorly in Switzerland. ${ }^{10}$ Of the 70,239 interbank transactions, solely 371 trades $(0.53 \%)$ were special repos, leading to yearly outstanding volumes between CHF 15 to 256 million (less than $1.2 \%$ of the total outstanding interbank volume). The poor development can among others be ascribed to the existence of Securities Lending and Borrowing (SLB), which has become very popular in Switzerland in the last few years. ${ }^{11}$

\footnotetext{
10 A comparison to the SNB market is not made, as no special repo transactions have been conducted on that market.

11 An additional reason is the size of the repo market. As the market is very small, the probability is very high, that the other party finds out that the bank is having trouble in closing out her short position.
} 


\subsection{Eligible collateral ${ }^{12}$}

On the Swiss franc repo market only a certain range of collateral can be used for GC repos. To define this range of eligible collateral it is best to distinguish between the SNB and interbank market. Eligible for repo transactions with the SNB are all assets that belong to the 'CHF GC Basket', the 'Euro GC Basket' and the 'German Jumbo Pfandbriefe GC Basket' (hereinafter 'German Jumbo'). These three baskets were combined to one basket, namely the 'SNB GC Basket', on 1 September 2003. ${ }^{13}$ The 'CHF GC Basket' consists of straight bonds, floating rate bonds, warrant bonds and money market debt register claims all with a minimum issue volume of CHF 100 million and denomination in Swiss francs. Securities issued by Swiss banks are not included, as the SNB does not want to lend money to the Swiss banking system and get securities, which are backed by the same system. ${ }^{14}$ On 18 October 2005, 667 assets were registered in the 'CHF GC Basket', adding up to a total nominal value of CHF 330 billion. Four hundred and twelve of these 667 assets were securities issued by foreign issuers and international organizations, possessing a minimum rating of 'A' from Standard \& Poor's or 'A2' from Moody's, representing about $46 \%$ (CHF 150 billion) of the total nominal value. The 'Euro GC Basket' in contrast, contains solely government bonds issued by six different countries (Belgium, Germany, France, Austria, Spain and The Netherlands). These government bonds are all denominated in Euro and fulfill the requirement of a minimum issue volume of EUR 1 billion. On 18 October 2005 the basket's total nominal value was EUR 2,740 billion, with Germany (40\%) and France (29\%) representing the countries with the highest shares. ${ }^{15}$ On 1 June 2006 the 'Euro GC Basket' was renamed 'Government GC Basket' and now contains government bonds denominated in euros, US dollars, pounds sterling and Swiss francs. ${ }^{16}$ The third basket is the 'German Jumbo', which contains German Jumbo ${ }^{17}$ mortgage bonds with a minimum issue volume of EUR 1 billion. This basket was first introduced on 26 February 2001 and requires that the issuers possess a minimum rating of 'AA' from Standard \& Poor's or 'Aa2' from Moody's. Since 1 June 2006 this basket is called 'International GC Basket' and additionally includes debt certificates issues by German territorial bodies and international organizations, and bonds issued by individual borrowers with state guarantees.

\footnotetext{
12 This chapter is based on SNB (2004a).

13 Until 1 July 2003, the basket known today as 'CHF GC Basket' was called 'SNB GC Basket'.

14 Cottier (1998), p. 39.

15 Until 4 March 2002, the 'Euro GC Basket' was called 'GER GC Basket' and consisted of government bonds from Germany. With the re-labelling on 4 March 2002, government bonds from Austria were added. Securities from The Netherlands were then introduced on 3 May 2004, while those from France, Belgium and Spain have been included into the 'Euro GC Basket' on 19 April 2005.

16 See Jordan (2006) and the SNB homepage for further details.

17 The term 'Jumbo' is used to refer to the larger, more liquid segment of the mortgages market and to a minimum issue volume of EUR 500 million.
} 
Table 1 The three baskets by comparison

\begin{tabular}{lcccc}
\hline & $\begin{array}{l}\text { Value } \\
\text { (bn CHF) }\end{array}$ & $\begin{array}{l}\text { In \% } \\
\text { of total }\end{array}$ & $\begin{array}{l}\text { No. of } \\
\text { securities }\end{array}$ & $\begin{array}{l}\text { In \% } \\
\text { of total }\end{array}$ \\
\hline CHF Basket & 330 & 6.5 & 667 & 59.6 \\
Euro GC & 4,256 & 83.9 & 277 & 24.7 \\
German Jumbo & 489 & 9.6 & 176 & 15.7 \\
Total & 5,075 & 100.0 & 1,120 & 100.0 \\
\hline
\end{tabular}

Source: SNB; own calculations Values as at 18 October 2005

Denomination has moreover been extended to US dollars, pounds sterling and Swiss francs. Furthermore the securities must now be rated at least 'AA-' from Standard \& Poor's or 'Aa3' from Moody's to be included in the 'Government GC Basket' or 'International GC Basket'. 18

Comparing the three baskets with each other shows that the 'Euro GC Basket' possesses the largest total nominal value in CHF, while the 'CHF Basket' contains the highest number of securities (see Table 1). The finding that the 'CHF Basket' incorporates more securities can be explained by the fact that the minimum issue volume is only CHF 100 million. On 18 October 2005 the average issue volume in the 'CHF Basket' was CHF 495 million and approximately $91 \%$ of the securities had an issue volume smaller than CHF 1 billion. With the extension of the baskets on 1 June 2006 the total nominal value of the 'SNB GC Basket' increased by about $20 \%$ and now reaches approximately CHF 6,000 billion. ${ }^{19}$

For interbank repo transactions conducted via the Swiss repo system, banks can use the 'SMI GC Basket' in addition to the 'SNB GC Basket'. ${ }^{20}$ However, this basket cannot be used for repo transactions with the SNB. This basket encompasses all components of the Swiss Market Index (SMI) and reached a total market capitalization of CHF 837 billion on 18 October 2005. In contrast to the other baskets, where the securities can be used for all contract types, the 'SMI Basket' can only be used for Overnight, Tom Next, Spot Next, 1 week, 2 week and non-standard repurchase transactions. The 1 and 2 week maturity as well as the non-standard repurchase transactions were the most frequently used contract types accounting for $88 \%$ of the overall 404 transactions. Table 2 reveals that the 'SMI GC Basket' was of minor importance for the total 231,198 GC transactions as this basket has only been used for $0.2 \%$ of all GC transactions. One explanation for the scarce use is that a bank can barely re-use the collateral obtained through a reverse repo transaction, as the SNB, as an influential and important participant, does not accept the 'SMI GC Basket'.

\footnotetext{
18 See Jordan (2006) and the SNB homepage for further details.

19 See the SNB homepage for more information on the total nominal value of the restructured and extended baskets.

20 The 'SMI GC Basket' was first introduced on 5 March 2001 and comprised the ten most liquid equities in the Swiss Market Index (SMI). In May 2001, the basket was expanded by five more equities before the remaining SMI titles were included on 19 August 2002.
} 
Table 2 The different baskets used from June 1999 to June 2005

\begin{tabular}{lccccc}
\hline Year & 'CHF GC' & 'Euro GC' & 'German Jumbo' & 'SNB GC' & 'SMI GC' \\
\hline 1999 & 8,427 & 320 & - & - & - \\
2000 & 21,817 & 4,290 & - & - & - \\
2001 & 24,761 & 3,735 & 3,289 & - & 144 \\
2002 & 30,890 & 3,947 & 5,839 & - & 162 \\
2003 & 26,418 & 5,352 & 6,927 & 7,632 & 38 \\
2004 & 1,018 & 175 & 637 & 47,881 & 47 \\
2005 & 672 & 25 & 262 & 26,480 & 13 \\
Total & 114,003 & 17,844 & 16,954 & 81,993 & 404 \\
\hline
\end{tabular}

Transactions based on 'SNB GC' before 1 September 2003 were added to 'CHF GC'. 'SMI GC' includes all SMI baskets whether it was composed of 10,15 or 27 equities. The 'GER GC Basket' used before the introduction of the 'Euro GC', was added to the 'Euro GC Basket';

Division was made according to the purchase date [Source: Eurex]

Additionally the treasury, SLB and asset management division are often separate bank divisions. Hence, while the treasurer cannot re-use the collateral received, the SLB division, for instance, could very well use the SMI asset to borrow another asset. Yet, as these divisions are separated, suboptimal communication and additional expenses avoid the acceptance of SMI assets for GC repos in the first place.

Before the introduction of the collective 'SNB GC Basket', the 'CHF GC Basket' was the most important one, accounting for $77 \%$ of all transactions from June 1999 to August 2003. After 1 September 2003, no precise statement can be made as the collective basket was mainly selected. That the 'SNB GC Basket' was mainly chosen can be ascribed to the fact that the collateral selection process is facilitated as securities from three different baskets can be selected for a repo transaction.

As market participants have mostly used the 'SNB GC basket', which consists of three sub baskets with different currency denomination and debtor categories, it can generally be concluded that since the introduction of the 'SNB GC basket' the repo rate is independent of the collateral provided. Hence, ignoring the transactions with the 'SMI GC Basket', it can be asserted that only one interest rate curve is traded per day.

\subsection{The Swiss value chain and triparty service system}

In Switzerland, repo transactions are normally conducted via the Eurex Repo trading platform and settled via SIS and SIC in collaboration with the SNB. ${ }^{21}$ This infrastructure also known as Swiss Value Chain enables a high degree of standardization and automation, eliminating settlement risks and increasing efficiency. The Swiss repo trading, clearing and settlement system was launched in June 1999 and has since then provided market participants with an integrated

21 SNB (2004a), p. 7. 
Table 3 Number of settlements and triggered margin calls

\begin{tabular}{llccc}
\hline & Margin security & Cash margin & Total settlements & Total transactions \\
\hline $2005^{\mathrm{a}}$ & 24,634 & 64 & 92,317 & 117,015 \\
2004 & 23,540 & 122 & 99,617 & 123,279 \\
2003 & 21,861 & 68 & 93,015 & 114,944 \\
$2002^{\mathrm{b}}$ & 9,367 & 10 & 81,099 & 90,476 \\
Total & 79,402 & 264 & 366,048 & 445,714 \\
\hline
\end{tabular}

Source: SIS

${ }^{\mathrm{a}}$ Figures are from January to October 2005

b Margin call and settlement figures are from July to December 2002 and January to December 2002 respectively

trading and clearing platform for repo transactions. This platform also serves the SNB to carry out its open market operations via repo auctions and to provide the Swiss banking system with intraday liquidity.

Repo transactions conducted via this platform are called Triparty repos as the cash taker and provider assign a third party, namely SIS, with the settlement, administration and risk management of the repo transaction. During the term, for instance, which is defined as the time between the purchase and repurchase date, SIS revalues thrice daily the collateral at market prices (mark-to-market) and calculates twice daily the net exposure ${ }^{22}$ a party holds vis-à-vis each participant. If this net exposure exceeds the unilaterally defined variation margin, which is the range within which it may fluctuate, the SIS requests a margin transfer of the whole amount missing from the party providing insufficient coverage. The margin transfer can either be made in the form of securities (margin securities) or cash (cash margin). According to the data provided by the SIS, institutions preferred to meet margin calls in the form of securities in more than $99 \%$ of the cases (see Table 3 ).

\section{Risks in the Swiss franc repo market}

The fully automated trading and settlement of securities as well as cash transactions on a simultaneous, final and irrevocable delivery versus payment basis, eliminates the settlement risk during the opening and closing of a repo transaction. Nevertheless the parties are exposed to a so-called market risk, as in most cases the business and purchase date differ from each other. ${ }^{23,24}$ Throughout this time period the counterparty could default and the settlement of the repo

\footnotetext{
22 The net exposure is calculated by offsetting all open positions (i.e. exposures) towards each counterparty considering all previously undertaken margin transfers.

23 The purchase date is not necessarily the date at which a transaction has been concluded (i.e. business date). The purchase date of a one week repo for example, is two days after it has been concluded.

24 See Csoport (2000), p. 107.
} 
Table 4 Arrears in the Swiss franc repo market

\begin{tabular}{lccc}
\hline & Number of arrears & Total settlements & Rate of arrears (in \%) \\
\hline $2005^{\mathrm{a}}$ & 9 & 92,317 & 0.00975 \\
2004 & 12 & 99,617 & 0.01205 \\
2003 & 22 & 93,015 & 0.02365 \\
2002 & 10 & 81,099 & 0.01233 \\
Total & 53 & 366,048 & 0.01448 \\
\hline
\end{tabular}

Source: SIS

${ }^{\text {a }}$ Figures are from January to October 2005

transaction would not be carried out. Yet, up to October 2005 this has never occurred in the Swiss franc repo market.

During the term, participants are among other risks subject to credit and liquidity risks. Credit risks arise from the volatility in the value of collateral, i.e. if for example the market value of the securities serving as collateral declines an under-collateralization may result. In the event of counterparty default, the collateral would have to be liquidated at the prevailing (lower) market price, leading to a loss for the cash provider. ${ }^{25}$ In Switzerland, credit risks are reduced by the daily mark-to-market process and respective margin calls, carried out and triggered by the SIS, as well as by variation margins, which can be adjusted to counterparty characteristics. As the variation margin is regarded as uncollateralized part of the loan, this amount will be subject to capital requirements. ${ }^{26}$ Unfortunately no precise statement can be made about the height of the variation margins chosen, but due to capital requirements, it can be expected that the participants have mainly chosen variation margins that are lower than CHF 200,000. Liquidity risks on the other hand can arise if the cash provider for instance has to sell the collateral due to counterparty failure, but the specific securities markets are rather illiquid (or become illiquid at times of market stress) or considerable price fluctuations emerge due to the selling of these securities. ${ }^{27}$ This type of risk is also reduced in Switzerland as securities are only accepted as collateral if they possess a minimum issue volume of EUR 1 billion or CHF 100 million respectively.

To sum up, it can be argued that the Swiss franc repo market is a market featuring low risks. The Swiss Value Chain as well as the Triparty Repo Service System provides an efficient clearing, settlement and risk management for the participants in the repo market. As for the market risk, it can be concluded that it virtually does not exist, as the rate of arrears has not even reached values higher than $0.02 \%$ (see Table 4). In addition the settlements in arrears that have

\footnotetext{
25 See BIS (1999), p. 26. For a distinction between actual and potential credit exposure, which is not drawn in this paper, as well as for a discussion on further possible risks, for instance operational risks, see Csoport (2000), pp. 97-152 and BIS (1999), pp. 26-28.

${ }^{26}$ For an overview on the current capital adequacy requirements (Basel I) and the revised framework (Basel II), see BIS (2005).

27 See BIS (1999), p. 26 and Csoport (2000), p. 114.
} 
occurred in 2004 and 2005, were not cancelled but rather met with a delay of 1 day. Credit risks too are minimized in the Swiss franc repo market, as all margin calls were met on the same day until October 2005 and as it can be expected that most of the participants chose a variation margin limit lower than CHF 200,000 .

\section{Participants in the interbank and SNB repo market}

To participate in the interbank and SNB repo market, banks must hold a sight deposit at the SNB, a securities deposit ${ }^{28}$ at the SIS and fulfill the terms of acceptance by Eurex, SIS and SIC. In June 2005, 99 banks were registered for participation in the Swiss franc repo market. While the domestic banks mainly participate in the Swiss franc repo market because of reserve requirementswhich will be discussed below-it can be seen in Table 5 that a large part of the registered participants, namely $45 \%$, are foreign banks. Moreover it can be seen in Table 5 that the main cash taker groups were big banks (UBS and Credit Suisse), banks from abroad and the Raiffeisen banks. In the following, a more detailed description on the development of the interbank and SNB market as well as the reason for participation of domestic and foreign banks in these markets, shall be discussed.

\subsection{The interbank market}

The interbank repo market has developed slowly compared to the SNB market, surpassing the outstanding volume of the SNB market only in April 2004 (see Fig. 1). As of June 2005, the interbank outstanding volume reached a level of approximately CHF 45 billion, which represents the highest level up to that date. Dividing the interbank volume over the last 5 years into the different maturities shows that on average $50 \%$ of the outstanding volume had a maturity of 2 months and more, while the 1 week to 1 month transactions as well as the very short maturities (Overnight, Spot Next, Tom Next) accounted for 27 and $12 \%$, respectively. As mentioned before, this can among others be ascribed to the fact that the SNB market has satisfied the short-term liquidity needs to a great extent.

The main cash taker groups were the big banks, the banks from abroad as well as the Raiffeisen banks. In the shorter maturities (up to 1 month), the two big banks were the most active cash takers, accounting for approximately $50 \%$ of the outstanding interbank volume. The share of the banks from abroad in contrast, amounted to about $30 \%$ in the 1 week to 1 month maturities and $15 \%$ in the very short maturities (Overnight, Spot Next and Tom Next). The

\footnotetext{
28 There are two types of securities deposits with SIS. The first is the ordinary deposit where banks hold securities to carry out normal repo transactions with the SNB and other banks. The other deposit is the so-called Custody Cover Account 'SNB' and enables banks to undertake special-rate repo transactions with the SNB as well as to get intraday liquidity.
} 
Table 5 Participants and their share of outstanding amount

\begin{tabular}{|c|c|c|c|c|c|c|c|}
\hline & \multirow[t]{3}{*}{ No. of banks } & \multicolumn{6}{|c|}{ Share (in \%) } \\
\hline & & \multicolumn{2}{|l|}{2003} & \multicolumn{2}{|l|}{2004} & \multicolumn{2}{|c|}{$2005^{\mathrm{c}}$} \\
\hline & & SNB & IB & SNB & IB & SNB & IB \\
\hline Domestic banks & 54 & 48 & 58 & 60 & 57 & 65 & 62 \\
\hline Big banks & 2 & 38 & 45 & 41 & 34 & 51 & 48 \\
\hline Cantonal banks & 20 & 1 & 2 & 2 & 1 & 0 & 1 \\
\hline Raiffeisen banks & 1 & 5 & 5 & 9 & 14 & 5 & 7 \\
\hline Regional and savings banks & 5 & 2 & 1 & 6 & 1 & 7 & 1 \\
\hline Other banks ${ }^{\mathrm{a}}$ & 26 & 3 & 5 & 3 & 7 & 2 & 6 \\
\hline Foreign banks & 45 & 52 & 42 & 40 & 43 & 35 & 38 \\
\hline Banks from abroad ${ }^{b}$ & 26 & 51 & 42 & 38 & 42 & 33 & 37 \\
\hline Foreign controlled banks & 15 & 1 & 1 & 1 & 0 & 2 & 1 \\
\hline Branches of foreign banks & 4 & 0 & 0 & 0 & 0 & 0 & 0 \\
\hline Total & 99 & 100 & 100 & 100 & 100 & 100 & 100 \\
\hline
\end{tabular}

Source: Eurex

Figures may not add up due to rounding

Participants division was made as in SNB (2004b) and as of June 2005

Outstanding amount was calculated from the cash taker point of view

a includes SNB, SIS, PostFinance, private banks, commercial banks and stock exchange banks

$\mathrm{b}$ incl. one bank from Liechtenstein

${ }^{c}$ From January to June 2005

Raiffeisen banks on the other hand were mainly active in the very short maturities reaching shares of total outstanding of circa $16 \%$. In the longer maturities, the banks from abroad and the big banks were the main cash takers, accounting for more than $83 \%$ of the outstanding volume since 2002 .

Looking at the cash provider side reveals that the categories big banks, cantonal banks, Raiffeisen banks and others (including, inter alia, mortgage banks and PostFinance) are the main liquidity providers in the interbank market. While the big banks were mostly cash providers in maturities between 2 and 12 months, the cantonal banks were more active in the liquidity provision of shorter maturities (Overnight to 1 month). ${ }^{29}$ The Raiffeisen bank group's share was almost constant throughout the different maturities, whereas the fraction of the category others was highest in the 1 week to 2 months maturities.

Minimum reserve requirements, the refinancing of loans and differences in liquidity positions can be regarded as the main reasons for the development of the secured interbank market. Differences in liquidity positions for instance arise due to different fields of activity. Investment banks for example possess less liquidity than private banks which mainly specialize in private banking. In

29 The finding that the big banks are one of the most important cash takers as well as provider, results from the fact that an anonymization has been undertaken with the dataset. Thus this finding could for example be generated by a situation where one bank is a cash provider and another a cash taker. 
the following two sections, the focus and discussion will be on the explanations such as the minimum reserve requirements and the refinancing of loans.

\section{Reserve requirements}

In Switzerland, as well as in other countries, banks have to fulfill liquidity requirements. The Federal Law on Banks and Savings Banks (Banking Law) stipulates among others that banks must have an adequate relationship between their liquid assets on the one hand and their short-term liabilities on the other hand. A distinction is made between a cash liquidity and total liquidity requirement. ${ }^{30}$ Currently, all institutions that have obtained a bank licence from the Swiss Federal Banking Commission (SFBC) fall under the term bank and thus have to fulfill these liquidity requirements. In addition, branches of foreign banks that may not necessarily need a bank license due to treaties with other states have to meet these requirements. ${ }^{31}$

Until December 2004 minimum reserve regulations were in two different laws. While arts. 16a-f of the old National Bank Act (oNBA) allowed the SNB to use minimum reserve requirements as a monetary policy instrument, arts. 15 and 19 of the Banking Ordinance (BO) regulated the cash liquidity requirement. As the SNB had not used minimum reserve requirements as a monetary policy instrument since 1977, they were abolished in the National Bank Act Revision in 2004. Cash liquidity in contrast, facilitates the smooth functioning of the money market and ensures that there is enough liquidity in the banking sector, which reduces the probability that the SNB has to act as 'Lender of Last Resort'. As cash liquidity mainly serves for monetary purposes, its regulation was thus taken into the National Bank Act (arts. 17, 18 and 22-24), as well as into the National Bank Ordinance (arts. 12-17) in May 2004. Since then, the requirement formerly known as cash liquidity has been called reserve requirement. ${ }^{32}$ While the required minimum reserves still have to amount to $2.5 \%$ of the average of the liabilities at the end of the three months preceding the reporting period, the definition of eligible assets and relevant liabilities has slightly changed. Eligible assets are coins in circulation, banknotes and sight deposits at the SNB, all with denomination in Swiss francs. Deposits with the postal checking accounts (PCA) and with other clearing institutions recognized by the SFBC were excluded. ${ }^{33}$ Medium-term bank-issued notes and liabilities arising from money market paper maturing within 3 months have been added as

\footnotetext{
30 Total liquidity requirements will not be discussed in this paper, as they do not primarily serve monetary purposes and have been fulfilled by more than $170 \%$.

31 Art. 2 of the Banking Law.

32 After a grace period to adapt to the changeover from cash liquidity to minimum reserve requirements, the change took place as of the first applicable period in 2005.

33 Cash holdings were kept so as to avoid unnecessary transfers of these liquid assets to sight deposits held at the SNB. Deposits with the PCA were excluded to avoid an uneven treatment in comparison to bank deposits, which would especially arise if Postfinance entered into the lending business. In addition, deposits with the PCA are not part of the monetary base.
} 
relevant liabilities, while liabilities towards other banks that also have to hold minimum reserves were excluded. ${ }^{34}$ The maintenance period for minimum reserves has remained unchanged since 1988. Minimum reserves have to be held on an average from the twentieth of 1 month to the nineteenth of the following month. 35

From 1999 to 2004 and 2005 banks fulfilled their cash liquidity requirement on an average of 134 and $124 \%$, respectively. ${ }^{36}$ Differing between bank groups indicates that the big banks held barely more reserves than required, while other bank groups such as cantonal banks, private banks, Raiffeisen banks held at least 120 and $114 \%$, respectively. Comparing the required reserves with the sight deposits held at the SNB indicates that these sight deposits cover approximately $60 \%$ of these reserves. It can thus be concluded that the reason for holding sight deposits at the SNB not only emanates from the liquidity needs of the interbank payment system (SIC) but also from liquidity reserve requirements. By requiring cash liquidity reserves, the SNB can therefore ensure a stable demand for central bank money. It can be estimated that the SNB satisfies approximately $50 \%$ of the liquidity needs via its daily repo auction. Nevertheless, banks money demand is not fully satisfied by the SNB, thus leading to an interbank market. In summary, it can be ascertained that one of the bank's main interest in participating in the interbank market as well as in the daily auction on the SNB market, is therefore the minimum reserve requirement, allowing them to get enough liquidity to meet the requirement. ${ }^{37}$

\section{Foreign banks}

While domestic banks and branches of foreign banks must fulfill the liquidity requirements, this regulation does not apply to banks from abroad. Still Table 5 shows that this bank group has had a high share of outstanding volume in the SNB as well as in the interbank market in the last 3 years, reaching values of up to $51 \%$. Dividing this group further in country of origin, shows that the majority of the banks comes from Germany (9), Austria (6) and Great Britain (4). Focusing on Austrian and German banks, an explanation for their active participation can be found in the amount of loans they granted in Swiss francs. ${ }^{38}$ In June 2005, Austrian banks had loans outstanding in Swiss francs that added up to EUR 53.5 billion. This outstanding amount represented $80 \%$ of foreign currency loans of Austrian banks and $37 \%$ of total foreign currency loans of

\footnotetext{
34 For a detailed list see art. 14 BO.

35 See Gygi et al. (2001) for a more detailed overview on the National Bank Act Revision.

36 November and December 1999 values were excluded due to Y2K effect. For 2005 the January and April observations were taken. Detailed data can be found in Tables B3 and B31 of the SNB's Monthly Statistical Bulletin.

37 For banks which are cash rich the main purpose is to reduce opportunity costs of holding cash.

38 Note that due to aggregation and anonymization, it is not known if the Austrian and German banks were very active in the Swiss franc repo market. Still, due to reasoning provided in this section, it can be assumed that they were active to a certain extent.
} 


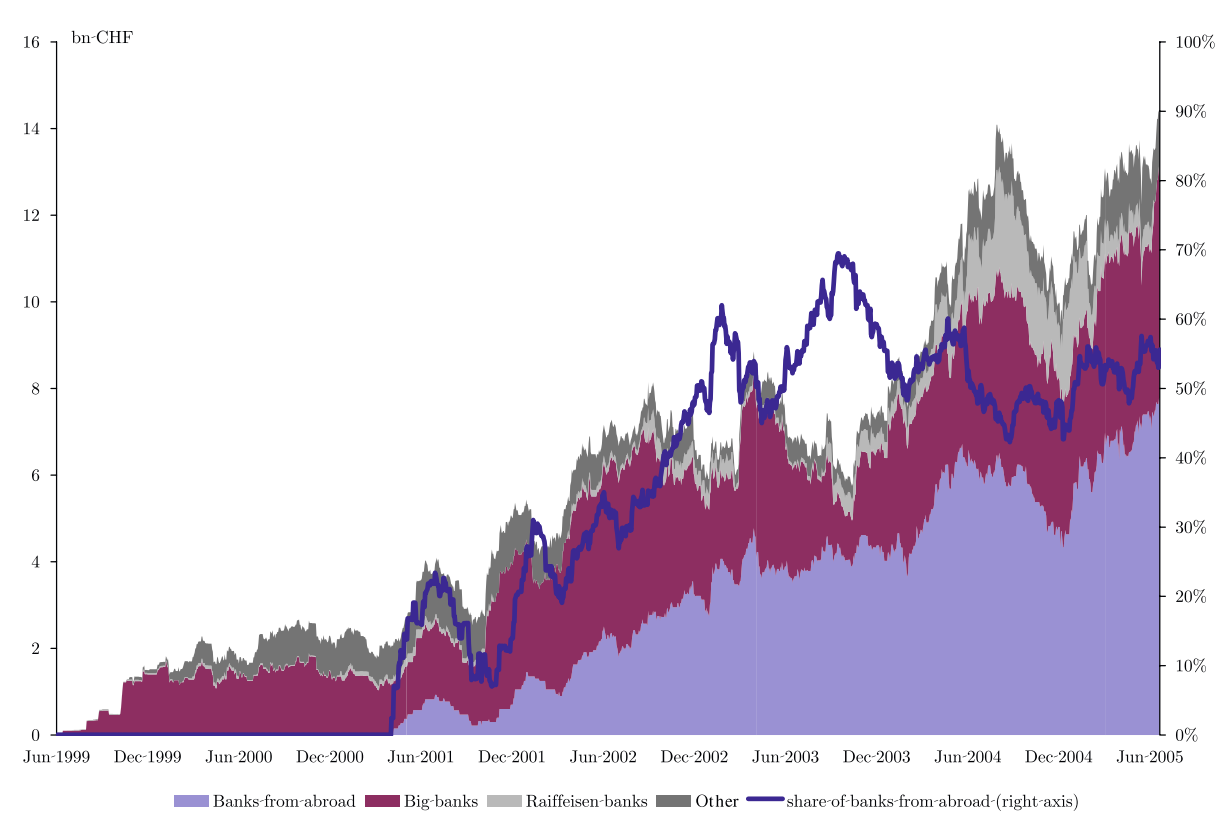

Fig. 2 Outstanding amount ${ }^{a}$ of 3-12 months interbank repo transactions. ${ }^{a}$ (Calculated from the cash taker point of view). Source: Eurex

all EU banks. ${ }^{39}$ The same applies for German banks, which had approximately EUR 31 billion of loans outstanding in Swiss francs. ${ }^{40}$ Hence the main reason for participation of Austrian and German banks is to refinance these loans on the Swiss franc repo market. Taking in the fact that longer maturity repo transactions are more convenient for refinancing and that maturities on the SNB market are normally up to 3 weeks, the focus was set on the different maturities of the outstanding interbank volume. As can be seen in Fig. 2, the 26 banks from abroad accounted for $50-70 \%$ of the outstanding volume of maturities between 3 and 12 months, underpinning the presumption of loan refinancing. Of course the volume received on the repo market does not fully cover the outstanding amount of loans granted. Further sources of refinancing are also bonds in Swiss francs. In 2004 bonds by Austrian debtors, for example, reached an issue volume of circa CHF 17 billion on the Swiss Stock Exchange in 2004. ${ }^{41}$ However, to which extent repo transactions and/or bonds have been used for refinancing purposes cannot be determined precisely. ${ }^{42}$

\footnotetext{
$3990 \%$ of the granted loans by Austrian banks (EUR 47.8 billion) went to residents within the EU. For further information, see the statistical database of the Austrian National Bank as well as Klein and Swoboda (2004).

40 See Deutsche Bundesbank (2005), p. 88 for further details.

41 See Jordan (2004), p. 5.

42 See Jordan (2005b) and Jordan (2004) for a further discussion on foreign currency loans.
} 


\subsection{The SNB market and open market operations}

About a year before the adoption of the new monetary policy framework, the SNB started using repos to implement its monetary policy. ${ }^{43}$ In 2000 , repos almost exclusively replaced currency swaps as main policy instrument, ${ }^{44}$ which is why the SNB market has developed so quickly. Throughout the last five years, the outstanding volume (excluding intraday) has almost always reached values between CHF 20 and 30 billion. Except for the regional and savings banks, the main cash taker groups are basically the same as in the interbank market, i.e. big banks, banks from abroad and Raiffeisen banks. In addition to the so-called main financing and fine-tuning operations, the SNB also offers a standing facility, namely a liquidity shortage and intraday facility. The intention of these two facilities is to allow banks to obtain liquidity to bridge unexpected, short-term liquidity shortages as well as to facilitate the settlement of payment transactions via the SIC. In the following, the outstanding amount and relative importance of the different facilities will be described and discussed.

\section{Open market operations}

Since 1999, the SNB has almost exclusively used the fixed rate tender ${ }^{45}$ to provide the banking system with liquidity. Nearly every banking day, the SNB announces the interest rate and the maturity of the contract and waits $10 \mathrm{~min}$ to allow the banks to submit the amounts they wish to obtain at that rate. The minimum and maximum amount per offer are CHF 1 and 100 million, respectively. Thus to obtain more than CHF 100 million banks need to submit more than one offer. In this fixed rate tender auction, the SNB then adds up all bids and decides if it will fully allot the amount bidded (100\%) or if it will allot pro rata, i.e. after an allotment of a minimum amount to each bank the bids are then satisfied to a certain percentage. As mentioned previously, the repo auctions are open for domestic as well as for foreign banks as long as they hold a sight deposit at the SNB and fulfill the acceptance requirements of Eurex, SIS and SIC. From January 2001 to June 2005 the SNB mainly used the 1 week (1W) maturity for its repo auctions (see Fig. 3). Looking at the development throughout the years, further shows that the importance of the overnight $(\mathrm{ON})$ maturity decreased while $1 \mathrm{~W}$ repos have become more and more important-since 2003 $1 \mathrm{~W}$ repos have been used in more than $75 \%$ of the cases. Figure 3 also displays

\footnotetext{
43 For a description on the new monetary policy framework see Jordan and Kugler (2004) and Jordan (2005a).

44 See Jordan and Kugler (2004), p. 4.

45 In a fixed rate tender, the interest rate and the maturity of the repo transaction is announced by the central bank. Apart from this tender, the central bank can also use a variable rate tender. In this kind of tender, bidders submit interest rate and quantity pairs to the central bank. The central bank will then choose an interest rate and will fully allot the bids that are above this interest rate. Bids with interest rates below the one chosen will be disregarded, while those at the chosen interest rate will be allotted pro rata. For a more detailed description of the two types of tender, see Bindseil (2002) and Välimäki (2003).
} 


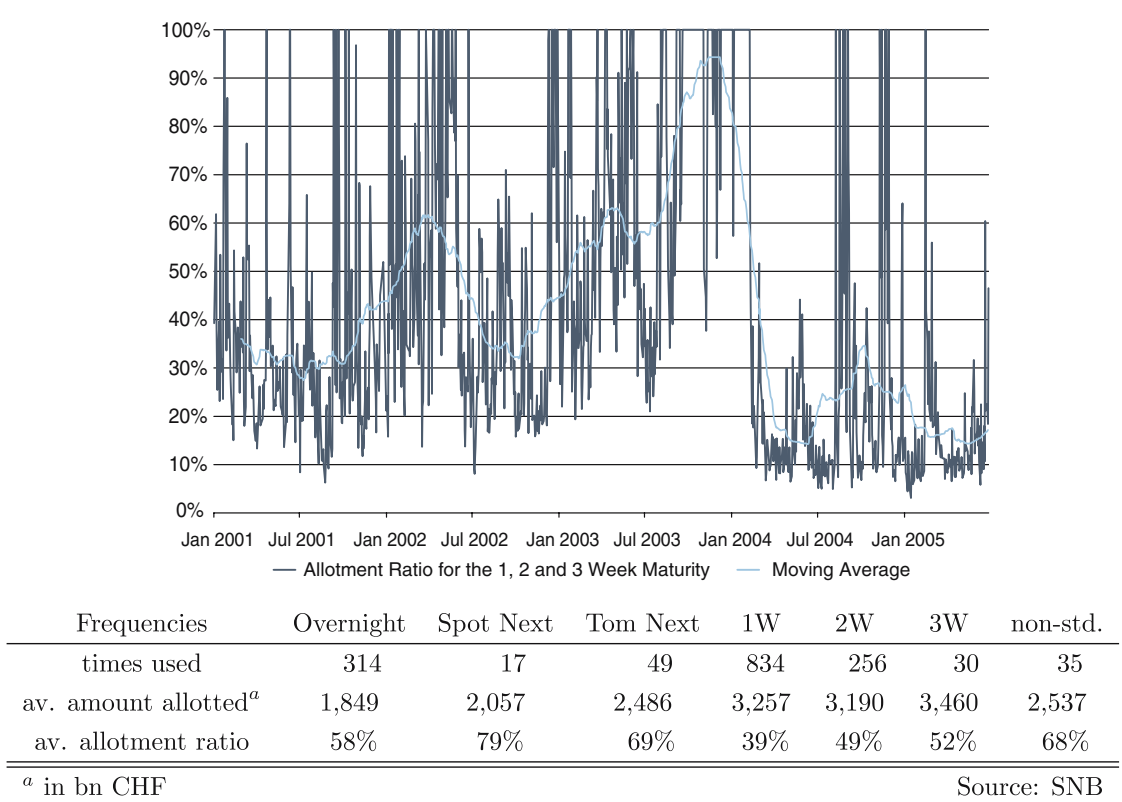

Fig. 3 Overview on the SNB Auction from January 2001 to June 2005 (in bn CHF). Source: SNB

the allotment ratio of auctions that used the 1,2 and 3 week maturity. While on average approximately $40 \%$ of the amount bidded had been allotted-it can be seen that the allotment ratio varied considerably across time. A comparison of the allotment and bid amount reveals that the variation in the allotment ratio mainly comes from the bid-side and not from the allotment side, as the SNB has always provided approximately the same liquidity (ranging from CHF 2-5 billion) to the banking sector. While a downward trend of the allotment ratio is apparent since 2004, the Swiss franc repo auction market is still far from the overbidding phenomenon experienced in the ESCB until June 2000 and will probably never end up in such a situation. ${ }^{46}$

In addition to the fixed rate tender auction, the SNB can also use fine-tuning operations conducted on a bilateral basis. The SNB uses this kind of repo transaction to offset undesired effects of external factors on liquidity supply and fluctuations in the short-term money market rates. Maturity and repo rate may differ from those of the repo auction conducted on the same day. Counterparties of the SNB can also request liquidity in the form of overnight funds if urgent liquidity needs arise. For such requests, the counterparty should normally notify the SNB before $3 \mathrm{pm}$. The SNB will then decide if it will supply additional liquidity or not, and will approximately charge 25 bp above the auction repo rate of the same day if it meets these needs. From 2001 to June 2005, the SNB has conducted repo transactions on a bilateral basis in 100 cases, using

\footnotetext{
46 See ECB (2000), Breitung and Nautz (2001) and Nautz and Oechssler (2006) for a review and discussion on the overbidding phenomenon in the ECB System.
} 
the overnight maturity almost exclusively. In three of these 100 cases, the SNB acted as a cash taker absorbing liquidity from the banking system.

For both, liquidity obtained through fine-tuning operations as well as through fixed rate tenders, counterparties have to cover the liquidity provided with at least $100 \%$ of collateral eligible for SNB repos.

Apart from the main financing and fine-tuning operations, the SNB also offers a standing facility, which consists of an intraday facility and a liquidity shortage financing facility. Intraday liquidity is provided by the SNB to counterparties on an interest-free basis and was introduced in October 1999. The procedure to obtain intraday liquidity is the same as for the main financing operations, except that the banks submit their requests for liquidity for the next bank working day at $4 \mathrm{pm}$. Since the introduction of this facility, requests for intraday liquidity have always been fully allotted. In addition, banks have the possibility to get further intraday liquidity on a bilateral basis up to the early afternoon of each working day. The main intention of the intraday facility is to facilitate the settlement of payment transactions via the SIC and foreign exchange transactions in the continuous linked settlement (CLS) system. Banks must cover the intraday liquidity provided with $110 \%$ of collaterals eligible for SNB repos. As intraday liquidity has to be repaid by the end of the value day, it is not considered for the fulfillment of the minimum reserve and liquidity requirements according to banking law. Looking at the intraday liquidity volume, it can be seen that this facility has become more and more important during the last years: While the average intraday volume reached a value of CHF 1,023 million in 1999, the amount in 2005 was six times larger (CHF 6,308 million).

The liquidity shortage financing facility in contrast enables banks to get additional liquidity to bridge unexpected, short-term liquidity shortages or to ensure that the minimum reserve requirements are met at the end of a reporting period. Until 2005, banks were able to get that kind of liquidity through conventional Lombard advances or through special-rate repo transactions. By the end of 2005, Lombard advances were entirely replaced by special-rate repos and as a result banks only have access to central bank money if they are linked up to the Swiss repo system. For special-rate repo transactions, banks need a limit that defines the maximum amount of liquidity that can be withdrawn. In addition they must open a Custody Cover Account 'SNB' with SIS, which has to be covered with collateral eligible for SNB repos at all times to at least $110 \%$ of the limit granted. The interest rate for this financing form is two percentage points above the Repo-Overnight-Index ${ }^{47}$ of the previous day. Special-rate repos were barely used in 2004 and 2005, reaching a turnover of CHF 0.52 and CHF 1.02 billion respectively. ${ }^{48}$ Regarding Lombard advances it can be ascertained that the yearly drawn advances decreased in the last few years: While

\footnotetext{
47 The Repo Overnight Index is a volume weighted interest rate of overnight GC transactions between commercial banks traded on the Eurex platform. In addition, transactions will only be taken into account if the securities provided belong to the 'SNB GC Basket'.

48 See SNB (2005), p. 41.
} 
the yearly average of drawn advances reached CHF 42.9 million in 2000, the average drawn advances amounted to CHF 10 million in $2003 .{ }^{49}$

\section{Conclusion}

Looking at the data from the previous sections, it can be concluded that the Swiss franc repo market, in comparison to the unsecured interbank market, has gained more and more importance for the management, allocation and equalization of banks liquidity positions. This mainly results from the capital adequacy requirements (Basel I) as well as from banking crises all over the world, which have increased the importance of risk considerations in money lending. In addition, the features of the Swiss franc repo market such as the highly standardized trading, clearing and settlement system have supported the development of secured interbank lending. This naturally had effects on unsecured lending. According to a major money market broking house in Switzerland, unsecured lending decreased by $28 \%$ since the introduction of repurchase agreements in 1999. While unsecured lending with maturities between 3 and 6 months remained unaffected, lending in the shorter end (up to 3 months) and longer end (6 months to 1 year) decreased by 30 and $20 \%$, respectively. Still it is assumed that the unsecured interbank market dominates the secured one. According to estimates by the $\mathrm{SNB},{ }^{50}$ it is assumed that the outstanding amount of unsecured interbank lending amounts to CHF 100 billion, thus 1.5 times the amount outstanding on the Swiss franc repo market. Unfortunately, no further precise statements can be made on the development of unsecured lending, as these transactions are mainly conducted over-the-counter (OTC) and are thus not publicly available.

Compared to other countries, only few publications have been made on the Swiss franc repo market. Explanations for the scarce publication landscape are the rather young repo market in Switzerland, as well as the absence of an overbidding phenomenon in the almost daily conducted repo auctions. Up until now, the SNB, in contrast to the ECB, has been spared by an extreme overbidding, which was experienced in the Euro zone from 1999 to June 2000. Data on the repo auction as well as the SNB's flexibility in meeting the banks liquidity needs, further lead to the conclusion that such an overbidding phenomenon will probably not occur in Switzerland. However, there seems to be an interest rate spread conundrum on the Swiss franc interbank market. Veyrassat (2004) compared the actual repo rates with the quoted depot rates (unsecured interbank lending) for 1 week and 3 month investments and established that between 2000 and 2003 the spread had narrowed from 9-11 bp to around 5-8 bp. Considering counterparty risks and capital adequacy requirements, the spread should theoretically be somewhere between 20 and 30 bp. Further research could therefore

\footnotetext{
49 For 2004, only the year-end value of drawn Lombard advances was published, which reached a value of CHF 6.6 million.

50 See Veyrassat (2004), p. 44.
} 
be done on spread calculations based upon actual repo and depot rates as well as on a cause analysis on the 'mispricing' of either repo or depot transactions.

In comparison to other central banks, such as the ECB or FED, which use a point target of the overnight rate, the SNB decided to steer a longer-term interest rate, namely the 3M-Libor. Further research could thus also be done by the comparison of transmission and stabilizing effects as well as by analyzing the effectiveness of monetary policy on the economy with different target rates. Provided that the further development of secured lending continues, it could very well be that the importance of the 3M-Libor, which represents an unsecured interest rate, decreases, thus asking for a new target interest rate for Swiss monetary policy.

Acknowledgments The author would like to thank C. Ravara, U. Beeler and P. Kugler for their support before and during the composition of the paper. I am also grateful to K. Hug, M. Pluess, M. Hengelhaupt, M. Schlegel, F. Gonzalez, A. Chiapolini as well as to T. Wyrsch for useful comments and the data provision. Last but not least I would like to thank J. Dyke for her linguistic support and two anonymous referees at the journal Financial Markets and Portfolio Management.

\section{References}

Bank for International Settlements: International Convergence of Capital Measurement and Capital Standards - A Revised Framework. Basel Committee on Banking Supervision (2005)

Bank for International Settlements: Implications of Repo Markets for Central Banks. Report of a Working Group established by the Committee on the Global Financial System of the central banks of the Group of Ten countries, Publication No. 10 (1999)

Bindseil, U.: Equilibrium Bidding in the Eurosystem's Open Market Operations. European Central Bank Working Paper No. 137 (2002)

Breitung, J., Nautz, D.: The empirical performance of the ECB's repo auctions: evidence from aggregated and individual bidding data. J. Int. Money Financ. 20, 839-856 (2001)

Cottier, Ph.: Das Repo - ein neues geldpolitisches Instrument. Quarterly Bulletin No. 3 of the Swiss National Bank, pp. 34-45 (available in German and French only) (1998)

Csoport, P.: Repurchase Agreements - Eine Analyse des Repo-Geschäfts unter besonderer Berücksichtigung der Einsatzbereiche und Risiken. Verlag Paul Haupt (2000)

Deutsche Bundesbank: Banking Statistics - Statistical Supplement to the Monthly Report 1. (2005)

European Central Bank: The switch to variable rate tenders in the main refinancing operations. Month. Bull, pp. 37-42 (2000)

Fleming, M.J., Garbade, K.D.: Repurchase agreements with negative interest rates. Federal Reserve Bank of New York. Econ. Financ. 10(5) (2004)

Gygi, U., Klauser, P., Baltensperger, E., Colombo, G.-A., Giovanoli, M., Kohli, U., Plavec, U., Merz, P., Rich, G.: Das neue Nationalbankgesetz: Bericht und Entwurf der Expertengruppe Reform der Währungsordnung (2001)

Heller, D., Nellen, T., Sturm, A.: The Swiss interbank clearing system. Available on the SNB homepage: http://www.snb.ch/e/snb/interbank/sic_artikel.html (2000)

Hock, T., Zimmermann, P.: Forecasting monetary policy in switzerland: some empirical evidence. Financ. Markets Portf. Manag. 19, 201-212 (2005)

Jordan, T.J.: Current money market developments. In: Speech held at the Money Market Event, Zurich (2006)

Jordan, T.J.: Umsetzung der Geldpolitik in der Schweiz. In: Schweizer Volkswirtschaft, Ausgabe 4 (2005a)

Jordan, T.J.: Die Geldpolitik der Schweizerischen Nationalbank und die Frankenrendite in Österreich. In: Speech held at the congress on foreign currency loans (2005b) 
Jordan, T.J., Kugler, P.: Implementing Swiss monetary policy: steering the 3M-Libor with repo transactions. Schweizerische Zeitschrift für Volkswirtschaft und Statistik 140(3), 381-393 (2004)

Jordan, T.J.: Wie beeinflusst die schweizerische Geldpolitik die Frankenrendite in Österreich? In: Speech held at the congress in Feldkirch, 23 September (2004)

Klein, A., Swoboda, G.: Zinssätze in Österreich 2004 nach wie vor kundenfreundlich - Fremdwährungskredite boomen weiter. Report of the Austrian National Bank (available in German only) (2004)

Nautz, D., Oechssler, J.: Overbidding in Fixed Rate Tenders - an emirical assessment of alternative explanations. Europ Econ Rev. 50, (3) 631-646 (2006)

Swiss National Bank: Guidelines of the Swiss National Bank on Monetary Policy Instruments including Appendix 1-5. 30 April 2004, available on the SNB homepage (2004a)

Swiss National Bank: Banks in Switzerland. 2004 edition, available on the SNB homepage (2004b)

Swiss National Bank: Rechenschaftsbericht an die Bundesversammlung. Available on the SNB homepage in German and French (2005)

Välimäki, T.: Central bank tenders: three essays on money market liquidity auctions. Bank Finl. Stud. E 26 (2003)

Veyrassat, A.: The Swiss franc money market: instruments and market participants. Quart. Bull. 3 of the Swiss National Bank, pp. 42-55 (2004)

Veyrassat, A.: Steuerung der Geldmarktsätze durch die Schweizerische Nationalbank. Financ. Markets Portf. Manag. 15, 344-362 (2001)

Wilhelmsen, B.-R., Zaghini, A.: Monetary policy predictability in the euro area: an international comparison. In: Working Paper by the Economics Department of the Norges Bank (2005)

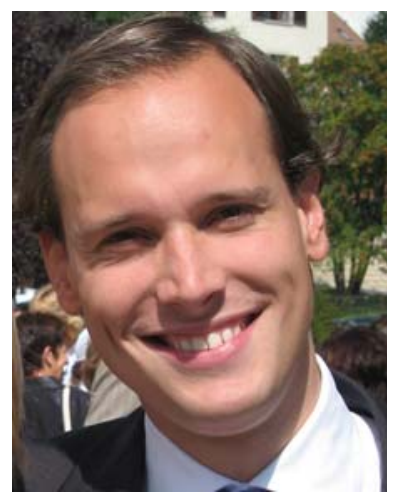

Sébastien Kraenzlin works as an economist at the Money Market and Foreign Exchange Division of the Swiss National Bank. Prior to this position he worked part-time at the Economic Research Department of Credit Suisse (Zurich) and completed two papers on Swiss Franc Repurchase Agreements for his thesis. His thesis advisor is Prof. Peter Kugler from the University of Basel. Sébastien Kraenzlin holds a Master's Degree in Economics from the University of St. Gallen (HSG) and completed the PhD Program from the Studycenter Gerzensee (Foundation of the Swiss National Bank). 